\title{
CIVIL WAR LETTERS OF MAJOR WILLIAM THOMPSON
}

\author{
Edited by Edwin C. Bearss
}

The following are selected letters from the complete collection of Thompson Letters for the period of August to December, 1862, published by the Washington County Historical Society, Fayetteville, Arkansas. The letters were edited by Edwin C. Bearss, historian.

The introduction, "Major William Thompson," was written by William G. Thompson, 66 Woodmere Lane, Tenafly, N. J., grandson of Major William Thompson. Besides presenting his grandfather's and grandmother's letters to the Iowa Department of History and Archives, Mr. Thompson also assisted in editing his grandparents' letters for publication.

\section{MAJOR WILLIAM THOMPSON}

William G. Thompson was born January 17, 1830, Centre Township, Butler County, Pennsylvania. He was the son of William H. Thompson and Jane Thompson. His father (William H. Thompson) was born in Allegheny County, Pennsylvania, December 1, 1796, and had moved with his parents to Butler County at an early age. He died August 19, 1867.

Major Thompson had two brothers (also born in Butler County). They were: Solomon Robert Thompson (born March 17, 1831) and John M. Thompson (born January 29, 1829).

At the age of 19 , William Thompson attended the Witherspoon Institute in Butler; his primary education having been obtained in the common schools near his boyhood home-and when not in school, he helped his parents on their farm.

William Thompson read law in Butler and was admitted to the Pennsylvania Bar October 15, 1852. The Honorable Daniel Agnew presided at his examination.

On November 27, 1852, Thompson decided to go west "as far as his money would take him," and he arrived at the small 
but thriving community of Marion, Iowa. There he met a young attorney by the name of Isaac $M$. Preston and went into law practice with him under the name of Preston \& Thompson.

On June 12, 1856, Thompson married Miss Harriet Jane Parsons, daughter of Chester L. Parsons, who had moved to Marion from upstate New York in 1850. Harriet Parsons had been born in Eldridge (or Elbridge) New York, June 30, 1836, and she died February 27, 1897-pre-deceasing her husband by 14 years. They had two children: William Chester Thompson (who died in infancy) and John McCandless Thompson (born May 24, 1875 and died August 23, 1962, in Marion, Iowa).

In August, 1854, William G. Thompson was elected prosecuting attorney of Linn County and held that office for two years.

He was elected to the State Senate on the Republican ticket (1856) and served for two years when he returned to practice law in Marion, Iowa.

He helped organize the 20th Iowa Volunteer Infantry. At a meeting held in the nearby town of Cedar Rapids, Thompson was selected as the Regiment's Major.

On December 7, 1862, Major Thompson was s everely wounded in the Battle of Prairie Grove, Arkansas, and was evacuated with the Union wounded of that battle to Fayetteville, Arkansas. He recovered there and re-joined the 20th Iowa Volunteers in time to be ordered to the siege of Vicksburg and took part in that campaign.

After the siege of Vicksburg, his regiment was stationed in, at, or near Carrollton, Louisiana, from which point they were sent to New Orleans and then boarded transports (along with a large Union force) for an amphibious operation against the Texas coast. He served as commandant on Padre Island (Post Aransas) for some time. While stationed there, Major Thompson led an expedition of 75 men and captured the town of Corpus Christi in a "hit and run" operation. In May, 1864, Thompson was permitted to resign from the service due to after effects of his wound and poor health from the siege at Vicksburg and returned to his home in Marion, Iowa.

Thompson was elected District Attorney for seven Iowa counties after his return to his law practice and filled that 
office for seven years. He was then appointed Chief Justice of the Territory of Idaho by President Rutherford B. Hayes and held that office for one term-resigning his appointment in 1879.

He was elected to the Congress of the United States in 1879 and took his seat in December of that year.

In August, 1894, Thompson was appointed Judge of the 18th Judicial District of Iowa and elected to that office in November, 1894, and re-elected in November, 1899.

He died in Kenwood Park, Iowa, (near Marion) on April 2, 1911, and is buried in Marion along with many of his comrades of the 20th Iowa Infantry in that place.

\section{LETTERS}

\section{Camp Kirkwood ${ }^{1}$}

Augt 12th/62

\section{Dear Jane}

I have only time now to say that me \& Pet got through all safe and I am verry [sic] busy now getting matters in shape. ${ }^{2}$ I do not sleep or eat yet in Camp for the reason that my quarters are not prepared but they will be this week. I have my uniform under way \& will have it this week.

I can not say whether or not I can get Home this week or not. But I will try when up at Lyons this day to have my measure for my uniform. Tell Clark to come down with Captain [Nathaniel M.] Hubbard's Company [F] \& have him

1. Camp Kirkwood was a Camp of Instruction for Union soldiers near Clinton, Iowa.

2. The ten companies that were to form the 20th Iowa Volunteer Infantry were ordered into camp by Gov. Samuel Kirkwood in the period July 15-August 15, 1862. William G. Thompson had been appointed major of the newly constituteed regiment on Aug. 1, by Gov. Kirkwood. Pet was the major's horse. Roster and Record of Iowa Soldiers in the War of the Rebellion, Together with Historical Sketches of Volunteer Organizations (Des Moines, 1908), Vol. III, 341,349 . 
bring my $1 / 2$ Buffalo robe as we forgot it yesterday. ${ }^{3}$

\author{
Ever yours \\ Wm G Thompson
}

\title{
My dear wife
}

Clinton, August 29th, 1862

I am still here \& can not say when I will get away. Matters are Just as when you left except that Mrs. Hubbard \& Mrs. Ristine have gone Home. ${ }^{4}$ Our Regt. is ready to move at any time \& why we do not is unknown both to Col. Dye \& myself, yet I expect to move soon from here to St. Louis at which place we will undoubtedly remain for some time. Where we may be ordered from that place I have not the most remote notion.

Our Boys are all well \& in good spirits, plenty to eat \& sleeping as good as you could expect under the circumstances. I have never had better health than at present \& I do believe that Camp life \& the exercise necessary thereto will give me a muscle not to be had in a Law office. ${ }^{5}$

Last evening, I for the first time took Command of the Regiment on Dress parade, and I feel some what flattered as I was the first officer that ever got through straight \& made no mistakes since we have been here. This I did easy as I had studied the matter well before I would take the Command, \& the Col requested me to do so \& I had no difficulty. The Col. is a gentleman in the full sense of the word.

Capt. Felix Vinson's Co. got here last evening \& so did Capt. [Wilbur C.] Dimmitt's, all on their road for Muscatine, where

3. Capt. Hubbard's company, which was mustered into Federal Service on Aug. 25, as Co. F, 20th Iowa Infantry, had been raised in Linn County. Henry $\mathrm{H}$. Clark of Cedar Rapids was a close friend of the Thompsons. Clark had enlisted as a musician in Co. A, 20th Iowa on Aug. 22, 1862. William G. Thompson to Bearss, Sept. 17, 1963. William Thompson is Maj. Thompson's grandson.

4. Mrs. Ristine was married to the regimental surgeon, Henry Ristine, Dr. Ristine, a resident of Marion, had been appointed surgeon by Gov. Kirkwood on Aug. 8, 1862. Roster and Record of Iowa Soldiers, III, 349.

5. Prior to entering Federal Service, Thompson had practiced law in Marion. 
[Colonel Eber C.] Byam's Regt is to Rendezvous. ${ }^{6}$ [Emmor] Ramsey is along and is a private in the ranks. ${ }^{\circ}$ We are all anxious to go to Dixie soon as possoble \& I think we will soon be gratified.

$$
\begin{aligned}
& \text { Love to you all } \\
& \text { Ever yours } \\
& \text { Wm G Thompson }
\end{aligned}
$$

My Dear wife

Camp Herron. ${ }^{8}$ Sept 5 th $/ 62$

Orders have come for our Regt to go to St. Louis \& I have Just made the order \& everything is bustle \& confusion besides that [it] is raining hard and verry [sic] disagreeable. I am writing on my knee \& You will no doubt have trouble in reading this scrawl.

I have been verry [sic] busy as I have had the entire command of the Regt for the last 2 weeks \& I have got along well \& I know I have the confidence \& respect of every man in the Regt. I have never made a request or an order yet that has not been most cheerfully complied with.

The Col. got here last evening, but has not yet assumed command, consequently, I have still the whole matter to superintend \& I must close for the present: I shall write to you soon as I get to St. Louis.

\section{Yours}

\section{Wm G Thompson}

6. Capt. Vinson's company, which had been raised in Linn County, Iowa, was mustered into Federal Service at Muscatine as Co. G, 24th Iowa Infantry. Capt. Dimmett's company which had been raised in Linn County, Iowa, was mustered into Federal Service as Co. F, 24th Iowa Infantry. Col. Byam of Mt. Vernon, Iowa, was appointed colonel of the 24th Iowa on Aug. 7, 1862. Ibid., 795, $820,891$.

7. Emmor Ramsey of Marion had enlisted in Vinson's company às third corporal on Aug. 13, 1862. Ibid., 875.

8. The 20th Iowa had marched from Camp Kirkwood to the Camp Herron Port of Embarkation on Sept. 1.: Camp Herron was at Davenport. C. Barney, Recollections of Field. Service with Twentieth Iowa Infantry Volunteers... . (Davenport, 1865), 20. 
Benton Barracks M O.

Sept 10th/62

Dear Jane

I never had my health better in the world than at present. I can eat more at one meal than I did at three before. We have not much of a variety but we have good wholesome food. We got some Butter to day which happened to come into Camp \& I discovered it \& got it.

We have our mess made up. It is composed of Col Dye, myself, Ristine, [Constant S.] Lake \& the Quarter Master. ${ }^{\circ}$ And we have one Cook, C. G. Martini, who by the way cooks well. We have no Table cloth. But we have a Tin plate, cup $\&$ knife \& fork each.

I have Two Blankets, one under \& one over, which makes a hard bed of course. But you would be surprised to see how well I sleep \& you know that I always had a partiality for a feather bed \& I can now tumble down on a board \& sleep sweetly.

We will go this week out to Rolla and encamp there for some time. How long I can not say. Rolla is 125 miles southwest of this place. And I learn that it is a little out of the way place not near so large as Marion. ${ }^{10}$ But this is so much better for us as we go there to learn the Drill. We will have nothing to divert our attention. The Drum calls for Dress Parade \& I must leave off \& go.

Yours

Wm G Thompson

9. Constant S. Lake was from Marion. Lake had been appointed regimental adjutant on Aug. 15, 1862. Jasper H. Rice of Iowa City was the regiment's quartermaster. Roster and Record of Iowa Soldiers, III, 349 .

10. In 1860, Marion's population was 1,421 , while Rolla had 1,438 inhabitants at the time of the Eighth Census. Population of the United States in 1860; Compiled from the Original Returns of the Eighth Census (Washington, 1864), 148, 295. 
Camp at Waynesville M O. Sept 18th 1862

My Dear Wife

After a march of 12 miles to day I am at this place in Company with about 4000 men. [There] being three other Regts beside our own. We have with us now, the $19 \& 20$ Iowa, the 20th Wisconsin \& the 94th Illinois.

We are now 36 miles from Rolla on our way to Springfield, and more God forsaken Country than that over which we have marched I have never seen. ${ }^{11}$ It is one hill after another, not only steep, but Rocky as it can be. The roads of course are solid as they can be for the reason that the ground is so stony it can't well get muddy.

But I forgot all my trouble \& vexation when I got here, as I found three of your letters waiting me here....

I am now writing on the top [of] our mess chest while our cook is doing up the Dishes. My mess have mostly gone to bed. But Dr Ristine is at the fire seated on a log of fire wood smoking, and looks well \& can sleep any place he lays down for the simple reason that he has energy \& life.

The Camp is vocal both with vocal \& instrumental music, and a thousand camp fires blaze all round me. The scene is one of animation \& life \& I do enjoy it. But while it would please me to see you, \& I would like to gratify your curiosity in looking at a live camp of soldiers, but you little know what you wish for, when you say you would come here if I would only say so. What in world would you do on the march? ${ }^{12}$ Not a place for you to ride except on top of some Box on the heaviest kind of lumber wagon with six Mules attached, \& a

11. Since the beginning of military operations in Missouri, thousands of troops had passed back and forth along the road from Rolla to Waynesville. The country through which the Federals marched was in the northern section of the Ozarks.

12. In her letter of Sept. 11, Jane Thompson had written her husband urging that he ask for a furlough. If this were impossible, she had inquired into the possibility of coming to see him. Should the major just say the word, Mrs. Thompson promised to be "there in less than a week." Jane Thompson to William Thompson, Sept. 11, 1862. 
swearing driver. When night comes if it does not rain, no Tents are pitched, \& if they are pitched, they are little \& uncomfortable. In short this is no place for a woman. If our Regiment was stationed in some place where a private House outside of Camp could be had \& the Regiment was going to stay some time, it would then be verry [sic] pleasant for all concerned. But not on such a march as we have now, nor in such a rascally mean country.

I have now over $\$ 350$ due me, but when we will see a Pay Master is a thing I can not say as they come here only when they can't help it. But it is good when he comes.

You would be surprised to see with what eagerness the Darkies go with us and in what numbers they come into Camp. Nearly every Capt \& Lieutenant has a Darkey to cook, \& they do it well and are the Jolliest fellows you ever seen, when they know they are free.

I have talked with the people along the road, \& of course they are all Union men now, \& say that [a] negro now is not worth a cent, as they leave them [the plantations] with impunity. Which last part is true, and there is but few negroes now in slavery along this route \& what are here are old superannated \& can't well run if they would. Farms are all dilapidated \& out of order, but little to eat except Hog \& Hominy. ${ }^{13}$

$$
\begin{aligned}
& \text { Ever yours } \\
& \text { Wm G Thompson }
\end{aligned}
$$

Springfield M O.

Dear Wife

Sept 25 th/62

You will see by the caption of this note that I have arrived at the renowned city of Springfield. And I must admit that after coming over so much miserable country as we have between here and Rolla that I was verry [sic] agreeably sur-

13. As the fortunes of war ebbed and flowed, tens of thousands of soldiers had passed back and forth along the road followed by the 20th Iowa on its march from Rolla to Springfield. Fourteen months of campaigning had taken its toll on the countryside. Farms had been despoiled and crops carried off by the soldiers and partisans. 
prised to find Springfield a rather pretty place, a most beautiful location \& a number one country round it.

The Town would undoubtedly be verry [sic] pretty had not the hand of treason mared [sic] its beauty. ${ }^{14}$ Many Houses are confiscated and now occupied by the Military. Fruit is abundant, good, \& cheap. And whenever the time comes that Yankee thrift \& industry hold the helm \& guides the ship of progress \& reform this portion of M O., although on the summit of the Ozark range and 2,500 feet above St. Louis, must \& will be the garden of this state. ${ }^{15}$ The truth is I would like to live in Springfield. The most splendid springs of water I ever seen are here all round the Town. Either of which will now, dry \& hot as the season is, supply an army of men \& beasts \& suffer no perceptible diminution.

I write this seated in my Tent with a board on my knee, the whole with myself \& Regt located on the famous Rebel Col John S. Phelps' farm, who is now in the Rebel army. ${ }^{18}$ And what a splendid beautiful farm it must have been, but the fruits of treason have been borne here. All the Houses are burned \& nothing but the Chimneys now stand, a lone monument of his wicked rebelion [sic]. Every rail that once inclosed his broad acres and splendid orchards have long since been used to Cook good Union men's dinners. The trees have been injured, indeed everything shows waste \& sad devastation.

14. Springfield had been occupied by Confederate forces on Aug. 11, 1861, following the battle of Wilson's Creek. Maj. Gen. Sterling Price and his Missouri secessionists had evacuated Springfield in the face of Maj. Gen. John C. Fremont's advance on Oct. 25. Following Fremont's relief by Maj. Gen. David Hunter, the Federals had pulled back to the railheads at Rolla and Sedalia. As soon as the Yankees had departed, Price's greyclads reoccupied the town. In February, 1862, Brig. Gen. Samuel R. Curtis' Army of the Southwest drove forward from Rolla. Price's Confederates evacuated Springfield on Feb. 12; Curtis' vanguard entered the city the next morning. The War of the Rebellion: A Compilation of the Official. Record of the Union Confederate Armies (Washington, 1880-1900), Series I, Vol. VIII, 59. (Cited hereafter as $O$. R.)

15. Maj. Thompson was mistaken. Springfield is west of the Ozarks. Springfield's elevation is 1,265 feet, which made the city 730 feet higher than St. Louis.

16. Again, Maj. Thompson was mistaken. Col. John S. Phelps was a prominent Union man of southwestern Missouri. 
The people here prefer to be Union, but their loyalty is only skin deep, and I would not trust many of them further than I could throw a fly. There is about 200 of the Butternuts who have been taken prisoner, and they are made to work on the fortifications being erected here for the Defense of this Town. ${ }^{17}$ They are working right in front of my tent. I have Just been out amongst them to see \& talk to them. The latter I did but little of, as they are not inclined to be communicative. But a more dilapidated Butternut-breeched set of JayHawkers never was seen together. They are as ignorant as Hottentots, but must work for they have a Bayonet at their rear. And having been used heretofore [to] driving negroes themselves, it is verry [sic] hard on their constitutions to have the same game played on them that they have played all their lives on others. It seems a Just retribution of Heaven that it is as it is.

I have also seen many of their slaves who have been set free by the Government on account of the Master being a Rebel. ${ }^{18}$ And it is amusing to hear their comments \& watch the broad grin of satisfaction which opens his face as he tells you that Marsa be a prisoner with a Bayonet at his starn a doing niggers' work on the fort for white folks. And they all appear to take a most malicious pleasure in telling it. They are Just as sharp as their masters and much more cunning. It would surprise you to see the number of them here now, all wanting a place, where he may earn something \& be with the army. Many of the females, or as they call them here nigger wenches, are importuning us every day to go as washerwomen, cooks, or at any work to be done but I refused to invest as I frankly admit I prefer a white person, although I wish the negro to have his freedom. But I can not have them round

17. While at Springfield, troops of the 19th and 20th Iowa threw up fortifications and guarded Confederate prisoners. Roster and Record of Iowa Soldiers, III, 225.

18. To deprive the Confederacy of the military and economic advantages of slaves, Congress in 1861 and 1862 passed Confiscation Acts which provided that all Negroes used in the transportation of stores or munitions or in work upon fortifications should be freed. Boatner, Civil War Dictionary, 171. 
me unless I can't get a white, although nearly every officer from 2nd Lieutenant up has them except Col Dye \& myself. And many of them are good cooks \& clean, yet others are worthless. It is with them like all others, some good others bad.

We have gone into camp here, and everything indicates that we will remain here for sometime. Where we may go I have no idea, as I can learn of no rebel army near us or in the state. ${ }^{19}$ We have heard of our victories on the Potomac \& you may be certain that our Boys had a heavy cheer over its reception. ${ }^{20}$

I was in hopes to have recd. a letter from you to day. But I failed in that expectation.

Yours

Wm G Thompson

Camp near Newtonia, M O.

Oct. 6th 1862

Dear Jane

I presume that by the heading above you could tell but

19. Unknown to Maj. Thompson and the officers of the 20th Iowa, Col. Joseph O. Shelby's hard-riding Rebel Cavalry brigade was camped at Camp Coffee, a short distance south of Newtonia, Mo. At this very moment, Col. Douglas Cooper's big bridgade was enroute from Scott's Mill in McDonald County, Mo., to Camp Coffee. The junction of these two commands would give the Rebels a formidable striking force in southwestern Missouri. O. R., Series I, Vol. XIII, 46-47, 297, 979.

20. On Sept. 14, the Army of the Potomac under Maj. Gen. George B. McClellan had defeated units of Gen. Robert E. Lee's Army of Northern Virginia at Turner's Gap. The next day, the Confederates under Lt. Gen. Thomas J. Jackson had compelled the large Union force at Harpers Ferry to surrender. At Antietam on Sept. 17, the Army of the Potomac and Lee's Army of Northern Virginia had met in a terrible battle. McClellan's troops were unable to hurl the Confederates into the Potomac River. Lee's men held their ground on the 18th, and under the cover of darkness, the Army of Northern Virginia retired across the Potomac. Lee's first invasion of the North had failed. 
little where I am. ${ }^{21}$ To be candid about it, I am not certain that I can tell you so as to make it intelligent to you. But one thing I can say that it is in the prettiest spot I ever seen in $\mathrm{M} \mathrm{O}$., and at the same time in the most out of the way place imaginable. I can not get a Postage stamp nor a pound of tea or salt. In fact there is nothing in the Country. It is entirely secesh, men, women \& Children. The Darkies are of course all Union and give us full information so far as they can.

I am ashamed to send this letter without prepaying. But I must do it or not write, for stamps can not be had. There is no mail in this place as it has been in the hands of the Rebels until yesterday, consequently, no U. S. Mails could run here.

We are now within one day's March of Arkansas and I think that about Tomorrow we will be there (at or near Cross Hollows better known as Pea Ridge).$^{22}$ But it is only guess

21. On Sept. 30, Brig. Gen. Frederick Salomon's division had attacked the Confederates at Newtonia. Salomon's troops had been defeated and compelled to fall back to Sarcoxie. At that time Salomon precipated the action on the 30th. Gen. John M. Schofield was concentrating a superior force to cope with Col. Cooper's Confederate division which had invaded southwestern Missouri. Gen. James G. Blunt and reinforcements were en route to the point of danger from Kansas, while Gen. James Totten's division had marched from Springfield on the last day of September. Gen. Schofield joined Totten's column on Oct. 1. Totten was directed by Schofield to turn his division into the Sarcoxie road. O. R., Series I, Vol. XIII, $18,696$.

22. Maj. Thompson was mistaken, Cross Hollows and Pea Ridge are not identical. Pea Ridge is a commanding plateau, separating the watershed of Big and Little Sugar creeks. On March 7 and 8, 1862, Gen. Curtis' Army of the Southwest had defeated the Confederate Army of the West in a battle fought on the slopes of Pea Ridge and in the fields and woods southwest and southeast of this commanding elevation. The Federals referred to this battle as Pea Ridge; the Confederates spoke of it as Elkhorn Tavern. Cross Hollows, about 15 miles south of Pea Ridge, was a place where both Federal and Confederate troops had camped during the Pea Ridge campaign.

Evidently, Thompson, when he wrote of Cross Hollows, meant Cross Timber Hollow. Cross Timber Hollow was the deep ravine bounding Pea Ridge on the east. The Telegraph road linking Springfield and Fort Smith ascended Cross Timber Hollow. In the fall of 1861, at the time of Fremont's occupation of Springfield, the Confederates had obstructed the Telegraph road, where it passed through the gorge with felled timber, hence the name Cross Timber Hollow. 
work with me. I only know that we are bound for Arkansas now.

But I must tell you of our first fight. On night before last (Oct $3 \mathrm{~d}$ ) at 5 in the evening we all had orders to prepare 3 days rations \& March at $7 .^{23}$ Just 2 hours notice. Rumor had been rife for days that a large body of Rebels (20000) were at this place to give us a fight, \& we guessed that our march was for this place. ${ }^{24}$ Our camp was near 30 miles from this place. ${ }^{25}$ But at 7 we all started. We took nothing with us except our blankets and Haversack with rations of bread \& meat. We marched hard all night, and Just a little before day light about 4 miles from this place we came onto their Pickets, which our Boys fired into. Killed one, wounded several \& took some Prisoners. We had with us about 8000 men.

Our Regt was in the center, consequently, we were a great ways behind \& could only hear the fuss. Our Boys went in on the run with a yell that would have done credit to a set of Indians. When we were within 2 miles of Town, a messenger came to us \& told us that our forces had been met by the enemy and that fighting had commenced, \& we could hear

23. Generals Schofield and Blunt met on Centre Creek on Oct. 3, to hammer out plans for an attack on the Newtonia Confederates. The plan outlined by Schofield called for a converging attack. Blunt's division was to take the main road from Sarcoxia to Newtonia. Several miles north of his objective, Blunt would divide his command. One column, with which the general traveled, would resume the advance along the main road. A second force was to strike toward the Rebels' left flank, marching via a country road. Gen. Totten's division was to march by way of the Jollification road and fall on the Confederates' right. Ibid., 288, 706-707.

24. Intelligence reaching Union officers concerning the Confederates' strength was inconclusive. Guesses ranged from a minimum of 13,000 to a maximum of 20,000. All told, Col. Cooper had about 7,000 troopers in and around Newtonia. Ibid., 19, 881 .

25. Totten's division spent Oct. 3 camped on Centre Creek. Ibid., 19. 
the cannon belch every minute. ${ }^{26}$ It was raining hard, \& we were all wet through and had marched hard all night \& had not eat a mouthful during the march, \& I tell you that a prospect of a Brush with the scoundrels was inspiring.

I gave Clark the overcoat \& Blankets \& told him to remain where he was out of Danger, \& I rode up the lines \& spoke a few encouraging words to the men, \& the double quick was ordered and we run for 2 miles. The Boys threw away overcoats, blankets \& Haversacks \& went in on their nerve. Not a man but 2 in the Regt showed the white feather. But I seen them trying to skulk \& I ordered them into their place, \& had they refused I would have shot the cowards as I would have shot a Dog.

Our Batteries in all near 40 guns took position, \& a few in advance opened on the Rebels. The 20th came into position quick \& in good order, \& when ordered to load, they done it quick \& in good order. I seen no quaking or fearing, but a determined look of fight along the whole line. We remained in place ready expecting every minute to see the rebels open fire. But when they did not, the truth dawned at once. The Rebels were runing [sic] like quarter Horses, \& had the start of us and all that we had made such a fuss over the rear guard of the Rebels who run [sic] soon as fired at. ${ }^{27}$

26. Col. Cooper and his officers had learned on the night of the third that the Federals were converging on Newtonia in three columns. Satisfied that he couldn't hold the village in the face of this powerful force, Cooper determined to fall back. To cover the Confederate evacuation of Newtonia, Col. Shelby had Capt. Sylvanus Howell unlimber his four-gun battery. One cavalry regiment was deployed to the right and a second to the left of the guns. Shelby hoped to delay the Yanks long enough to allow the Confederates to save their trains. As soon as the Federals came into sight, the Rebel artillerists opened fire. Ibid., 19, 307, 310, 311.

27. After the artillery duel had been in progress about 15 minutes, a courier galloped up to Shelby's command post with news that the wagon train had cleared Newtonia and had turned into the Pineville road. Shelby accordingly passed the word to retire. Some confusion accompanied the withdrawal; the 34th Texas Cavalry almost got cut off. Nevertheless, the Rebels reached the timber southwest of Newtonia well ahead of the advancing Federal cavalry. As they pulled back, the greyclads were harassed by the longrange fire of Union guns. Ibid., 307, 310 . 
Our Boys never fired a gun, \& but one of our Batteries fired. We killed a few of them, how many I never went to see \& we took some prisoners. ${ }^{28}$ Had not one of the Pickets escaped \& got in \& alarmed the Rebels we would have bagged about 5000 Butternuts. $^{29}$ We will have in our army at Cross Hollows about 25000 men, an army big enough to march through all this part of secesh. ${ }^{30}$

I picked up after the battle one of the finest duelling Pistols I ever seen. It is verry [sic] fine workmanship, silver mounted with some southern Nabob's coat of arms set on it in silver. I suppose it never cost less than $\$ 30.00$.

\section{Ever Yours \\ Wm G Thompson}

\section{Cassville M O.}

Oct 14th 1862

Dear Jane

On yesterday we recd. a large mail, upon the arrival of which I took my seat along with the Post Master in his Tent \& waited anxiously for about Two Hours for some letters from you which I expected to get. But I seen the last one go and none for me. Every one had letters But me. To day another large mail came and I repeated the same process with the same result. I have not had a letter from you for near Two weeks \& it seems to me about Two months. I really feel uneasy, for had you been well I think I would have heard from you.

28. Gen. Schofield reported that losses at Newtonia in the engagement on Oct. 4, had been "trifling." Ibid., 311.

29. Maj. Thompson was mistaken as to the importance of the escape of the Confederate pickets. Late on the previous afternoon, Rebel patrols had pinpointed Totten's division as it left Centre Creek. This news was promptly forwarded to Col. Cooper's Camp Coffee command post. At almost the same moment, a courier came thundering up the Pineville road with dispatches from Brig. Gen. James Rains. Rains, Cooper's immediate superior, had placed himself on record as unable to send any reinforcements, and he wanted Cooper to abandon his advance position and retire into Arkansas. Ibid., 332-333.

30. When concentrated, Gen. Schofield's recently constituted Army of the Frontier would muster about 20,000. Ibid., 21. 
We voted to day. ${ }^{31}$ The Republican Ticket had in our Regt 340 votes, the Democratic one had 68. Bully I say for the 20th Iowa Regt.

But I had almost forgotten to say where I am at this time. Well Cassville is in Barry County M O., about 10 miles from the Arkansas line. I suppose secesh now thinks that the sacred soil of slavedom has been abused by us at a woeful rate by not only marching an army of 20,000 men to their Homes, but actually holding a Republican Election under their nose. Well I am happy to say the experiment has been a most successful one.

The last time I wrote you it was from the Camp [Gadfly] in the woods about 12 miles from Newtonia in rain \& mud. But the weather soon cleared \& we have had most beautiful days for some time. We marched here on day before yesterday. We have a nice Camp \& good quarters. And have now here an army of about 20,000 men \& more coming, \& not a Rebel near that I know of, for when they run [sic] from Newtonia, as I wrote you, they had not halted at last accounts. ${ }^{33}$

31. Of chief interest to Maj. Thompson and the other Iowa soldiers was the election of a United States Representative from the Second District. The candidates were: William Vandever of Dubuque, a Republican, and William E. Leffingwell, a Democrat. Vandever defeated Leffingwell. Beisel to Bearss, Sept. 16, 1963.

32. If one followed the Telegraph road, it was 15 miles from Cassville to the Arkansas line.

33. Gen. Francis Herron's division on Oct. 14, reached Cassville from Crane Creek. Reports reaching Gen. Schofield at this time pinpointed Gen. Raines with 4,000 Rebel infantry and eight guns at Cross Hollows. Although their exact positions couldn't be determined by his scouts, it was believed by Gen. Schofield that Cooper's, Coffee's and Shelby's mounted commands were camped between Cross Hollows and the Indian Territory. O. R., Series I, Vol. XIII, 735-736.

On Oct. 14, an important meeting took place at Gen. Rains' command post at Holcomb's. Though they talked for hours, the Confederate leaders were unable to come up with a plan which was satisfactory to all concerned. As a compromise, Col. Cooper was to take his Indian units and Howell's Texas Battery and march against Fort Scott. Before starting for Kansas, Cooper was to detach his four Texas cavalry regiments. The senior officer present, Col. Thomas C. Bass, was to take charge of the Texas Cavalry Brigade.

(Footnote continued on next page) 
Where we will go, I can not say for I do not know, But I think to Little Rock. ${ }^{34}$

There is at present no prospect of a fight. We have a good many Prisoners \& all tell pitiful tales of course. There is still some Jayhawkers in the woods. ${ }^{35}$ But they keep hid when we are about as they know their doom if caught. ${ }^{36}$

You can not have the most remote idea of the amount of brutal ignorance extant in this vicinity. It would indeed be a most refreshing sight to see Calico \& Hoops on a tidy woman or a decent suit on a man. Most of the men have left \& all you see is long necked, yellow skined [sic], dirty women \& filthy children. Many of them as innocent of apparel as was Adam \& Eve in the days of Paradise. This is no foney [sic] picture. It is a sad reality \& the war with its Brutalizing effects has not mended either their manners or general appearance.

Coffee, Tea \& sugar are things that they talk of as belonging to the past, But now strangers to them all except as they beg a little from the soldiers, \& it is rather strange to see one of these ignorant Bipeds sitting cross leged [sic] at the door and ordering a negro woman or Two to do the work. The slave in many instances being the whitest \& smartest of the Two. It is to me most disgusting, \& it needs no great fore sight to tell where slavery exists, for in all cases you will see neglect,

Cooper's column broke camp at Elm Springs on the 16th. The march into Kansas would be made by way of Maysville. When he reached Old Fort Wayne on the 17th, Cooper halted his command to wait for several detached units to report. Following the departure of Cooper's column, Rains' infantry and artillery and Shelby's cavalry marched eastward and took position near Huntsville. Bass' Texans were posted at Holcomb's to cover the Telegraph road. Ibid., 47, 334 .

34. Gen. Schofield and his immediate superior, Gen. Curtis, had much more modest plans than Maj. Thompson gave them credit for. At most, Schofield hoped to whip Rains or drive him south of the Boston Mountains. If he should do this, Schofield felt that it would enable the Federals to occupy the northwest corner of Arkansas and pacify the Indian Territory. Ibid., 749.

35. Maj. Thompson has mixed his terms. Jayhawker was the name Confederates applied to Union partisans, while Rebel guerrillas were referred to as bushwhackers.

36. If caught, a bushwhacker was generally hanged; a similar fate awaited a jayhawker falling into Rebel hands. 
dirt and most unchristian slovenliness prevail \& that too where Yankee thrift would make the land teem with golden harvests \& the Orchards bend with splendid fruit. Nature has done much. The institution of slavery has ruined all.

You will no doubt see \& hear many rumors of fights \&c down here. But put no confidence in them for they are all got up to make some paper sell well.

I was up all night last night in charge of the Picket Guard. I had 300 men under my charge to keep the out posts. I like it verry [sic] well \& get along first rate. I am still acting as Lieut Colonel of the 20th, and never had my health better in the world. I have gained about 11 pounds since I have been in camp.

Clark is not altogether well. He has had the M O. quickstep but is now about well. ${ }^{37}$

"My Dear wife"

Yours

Wm G Thompson

Camp at Pea Ridge, Arkansas

Oct 20th 1862

Again I am seated to have a short talk with you, an[d] tell you of our travels. ...

On day before yesterday we left Cassville and marched 25 miles to this place. We are now encamped on the old Battle ground of Pea Ridge. ${ }^{38}$ I have been over . . the ground, and on every hand its witnessed marks of the war storm. Trees \& bushes all over the ground are scared and torn with Canon [sic] Ball, Musket Ball, shell, grape \& canister. I seen many large trees almost cut in Two with Canon [sic] Ball.

I visited the Burial place of our Iowa 9 th \& find a few names which I recognize as our Boys from Marion. ${ }^{39}$ They

37. The Missouri "quick step" was the soldiers' name for diarrhea.

38. When the Army of the Frontier debouched from Cross Timber Hollow, Schofield told his division commanders to have their units camp in the fields south and southwest of Elkhorn Tavern. The tavern would serve as army headquarters. O. R., Series I, Vol. XIII, 747.

39. The 9th Iowa Infantry had been heavily engaged on March 7, near Elkhorn Tavern. In this fighting, the regiment had lost 38 killed, 176 wounded, and 4 missing. O. R., Series I, Vol. VIII, 205. 
sleep on the summit of Pea Ridge in a dry spot. Their graves are shaded by oak trees, as nature planted them, which grow profusely all over the country. In fact the battle field is one mass of brush and timber, much thicker than those opposite Father's door on the old hill side.

We are now having most beautiful weather, in fact frost has not reached here yet. The Country, however, as a general thing is worthless, being a succession of hills and vales, not only stoney but actually and literally paved with stone. Not unlike some parts of Penn except that the stones here are small more like pebbles, verry [sic] hard and completely cover the surface of the ground, so that it is impossible to dig a hole for tent poles, \& before you can put the Blanket down on which to sleep, we take a spade and shovel the stones off the top \& get a place smooth as possible. The climate I think a fine one, and at this season of the year is undoubtedly healthy. But so far as farming is concerned, it is of but little account.

We have now marched 250 miles through $M O$. and this far in Arkansas, \& we have never as yet seen one single School House. And I assure you that where School Houses are not, Rebels are plenty. This rule is universal, for treason and ignorance are in all cases Twin Brothers. Nearly every House we come to is deserted by men. Every one capable of bearing arms are in the rebel army either willingly or unwillingly, for the conscript act is enforced and the men between $15 \& 60$ years of age have no choice but go in or loose their life, \& thousands would gladly come to us if they could but safely do so. ${ }^{40}$

About 5 o'clock PM last evening we got an order stating that our advance guard and forces were engaged with the enemy, who had made an attack upon us unexpectedly and for us to

40. Thompson was mistaken on the age groups to which the Confederate Conscription Act applied. On April 16, 1862, the Confederate Congress passed a bill conscripting for three years' service all white males between 18 and 35 who were not legally exempt. In September, the age limit was raised to 45 . Boatner, Civil War Dictionary, 172. 
be ready to march at a moment's warning to battle. ${ }^{41}$ The Drums were beat, \& we were all ready in 5 minutes, officers \& men. I could not help thinking all the time that it was strange that an enemy could be within 5 miles of us, \& come up \& attack us, \& none of our 20000 men know any thing of it or of their presence in the vicinity. We remained under arms for Hours. I was on my horse all the time, yet no orders to march. A messenger came in from the advance, \& said he was in the fight and that there was thousands of Rebels, \& plenty of Artillery all pouring into our men and ours giving it to them and hard fighting generally. ${ }^{42}$ But still no orders to march. I stood it for about 3 Hours. I then got off my Horse \& took my blanket \& laid down before the fire \& fell asleep.

About 11 o'clock I was awoke by some one \& told to put up the Horse (which means taking off Bridle \& saddle \& tieing [sic] him to a tree), and for the men to sleep under arms which they did. I went into bed in the Tent \& slept until sunrise....

This morning, however, we learn that the whole excitement resulted from a skirmish between our Pickets \& about Eighty Bushwhackers which our men cleaned out in a verry [sic] short time without loss. Now this is the whole of the big fight No. 2 at Pea Ridge, yet you will no doubt see some great accounts of the fight and what prodigies of valor were performed then and there.

I have actually seen accounts of our Newtonia fight in which it was solemnly asserted that we fought 2 hours, Killing 100 rebels \& c. Now the truth is, we never fired a gun nor did we hear one, and all the Killing done was by the advance Guard,

41. On Oct. 19, the 2nd Kansas Cavalry, which Schofield had sent on a forced reconnaissance down the Telegraph road, had penetrated to within three miles of Holcomb's. The leader of the Kansans, realizing that his regiment was dangerously isolated, passed the word to fall back. W. S. Burke, Official Military History of Kansc's Regiments, During the War for the Supression of the Great Rebellion (Leavenworth, 1870) 83-85.

42. The messenger, if Maj. Thompson had heard correctly, had given an exaggerated account of the clash between the 2nd Kansas and Bass' Texas Cavalry Brigade. Ibid. 
who shot a few Indians, who wanted to surrender, but whose intentions were not known at the time \& were shot. And we also captured a few wagons \& horses. But they [the Confederates] run too soon \& never attempted to make a stand.

You will see how easy it is to get up these reports. Put no confidence in them, for we will know when we are to have a brush with them. But the Rebels are still retreating as fast as they can and have not even made a show of resistance. ${ }^{43}$

Yours

Wm G Thompson

My Dear Wife

Camp Lyon, M O.

Nov 27th 1862

As I seat myself this night in my Tent to write you a few lines, old and now dear memories come to me. . . . But the day has not been passed without some of the creature comforts enjoyed at Home on these occasions [Thanksgiving]. I told you in my last [letter] that I had an invitation to Dinner this day \& that I would attend to it when the time came round. This Morning before I left for the court [martial], I had Two more invitations to Dinner and Two more after I got there. But I had accepted Capt Barney's and had to decline the rest.

At noon I went as agreed, and when I went into the Capt's Tent, I was surprised to find a Table on which was spread a

43. Patrols sent by Gen. Schofield upon his arrival at Elkhorn Tavern returned with much interesting information concerning the Confederates' dispositions. Rains was reported to have divided his command: Cooper was said to have gone off toward the Indian Territory. Examining his maps, Schofield decided that Cooper planned to raid his Fort Scott supply line. Rains with the Rebel infantry and most of the artillery had left Holcomb's and was marching eastward toward Huntsville. A brigade of cavalry (Bass' Texans) had been left to screen these movements. When he relayed this information to Curtis, Schofield concluded that the Confederates planned to abandon northwestern Arkansas. Rain, he wrote, would probably unite with Cooper and withdraw into the Indian Territory, or endeavor to double back into Missouri. $O$. R., Series I, Vol. XIII, 747. 
clean, neat white Table cloth, the first I have seen since I left St Louis, and what was better it was well loaded down with verry [sic] excellent eatables. The Bill of fare was as follows: Hot biscuit, Apple \& peach pie, Honey, Stewed Oysters, Mashed potatoes, Tomatoes, Tea \& sugar.

Now considering we are in the wilderness, I think we done [sic] admirably. And I forgot to add that we had good Iowa butter. How he [Capt. Barney] managed to keep them this long, I can not say. But after eating hard crackers, \& c., as long as I have, \& then get at such things was comeing [sic] out of desolate Egypt into the land of promise. I assure I did ample Justice to the meal. This I done [sic] by remembering My old trick when eating string beans \& quietly slipping a couple of Buttons on my Pantaloon's waist Band.

I finished Dinner \& came down to my Tent, and found that some one had been there \& left a fresh venison Ham for me. Who it was I can not say, but I do know it was a nice present. It is fat and tender, and this is the 2nd time since I have been in Camp here that I had the same present.

\author{
Yours only \\ Wm G. Thompson
}

Fayetteville Arks.

Dec 10th/62

My Dear wife

I presume you have ere this reaches you heard that we have had a battle. God Knows what you may have suffered on my acout [sic] by the conflicting rumors you may have heard \& not Knowing what had been my fate. ${ }^{44}$ When I last wrote you, I informed you that we were on our march south \& what

44. The battle of Prairie Grove which was fought on Dec. 7, had ended in a sweeping Union victory. 
a march we had. ${ }^{45}$ In three days \& nights we marched 110 miles \& got up with the enemy about $1 \frac{1 / 2}{2}$ oclock PM. ${ }^{46}$ At 2 P.M. without one moment's rest or halt, we attacked the enemy who had got a strong position on a wooded hill. ${ }^{47}$ Our Batteries opened on them fearfully. About $1 / 2$ after 2 the order was Limber to the front [and] advance Infantry, which we did with alacrity up through the field into the woods through a perfect hail storm of Bullets. I was on my horse all the time

45. Col. Daniel Huston's Second Division of the Army of the Frontier broke camp at $3 \mathrm{a} . \mathrm{m}$. on Dec. 4. The 20th Iowa turned into the Telegraph road. Nightfall found the Iowans camped at the Three Widows, 12 miles northeast of Cassville. The next day, the fifth division marched through Cassville and Keetsville, the 20th Iowa halting for the night two miles southwest of Keetsville. In the two days since leaving camp Lyon, the troops had marched 43 miles.

On the morning of the sixth, the troops were on the road a little before daybreak. It was about 5 p.m. when Col. Leake halted the 20th Iowa at Cross Hollows. The troops were permitted to rest for five hours. At 10 p.m. the march was resumed. It was sunrise when the column tramped into Fayetteville. The troops halted a mile southwest of the town for breakfast and to snatch a few moments of much-needed sleep. Within about 90 minutes, the soldiers were aroused by the distant roar of artillery. Quickly falling in on the double, the division advanced rapidly. Fording Illinois Creek, the troops filed into position on the battlefield of Prairie Grove at 12 noon on Dec. 7. O. R., Series I, Vol. XXII, pt. I, 118, 120.

46. The soldiers of the 20th Iowa had marched 100 miles in 80 hours, the last 57 miles having been hiked in 31 hours. Ibidl, 120.

47. Unlike Herron's column, Confederate Gen. Thomas Hindman's movements were lethargic. Nightfall on the sixth found the Rebel infantry and artillery at Morrow's. During the day Gen. John S. Marmaduke's Rebel troopers drove into Blunt's outposts. While he was maturing his plans for an attack on Blunt's division, Hindman was advised by his scouts of the approach of Herron's command. Since his corps lay between Herron and Blunt, Hindman determined to beat the Federals in detail. He would hit Herron first and then fall on Blunt. Masking his movements by having one of his cavalry brigades feign an attack on Blunt's division, Hindman put the remainder of his corps in motion toward Herron's column.

Marmaduke's cavalry encountered Herron's troopers and drove them back on Fayetteville. Herron called up his infantry and checked Marmaduke. Hindman thereupon brought up his infantry, but instead of attacking as he should, he took a strong position on a wooded ridge overlooking Crawford's Prairie and awaited Herron's attack. Ibid., 189-241; Thomas L. Snead, "The Conquest of Arkansas," Battles and Leaders of the Civil War, III, 449-450. 


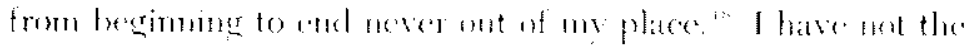

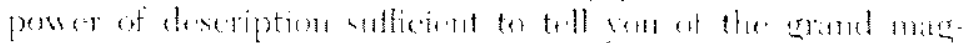

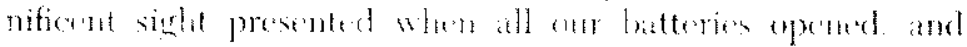
nur whole lime for more than a mile in lometh commenered

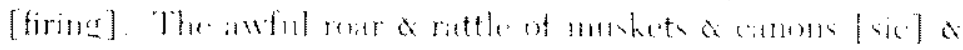

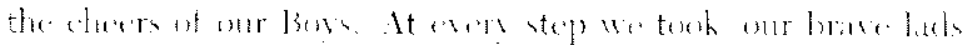

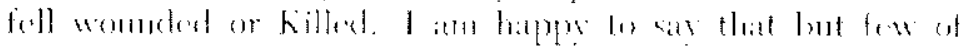

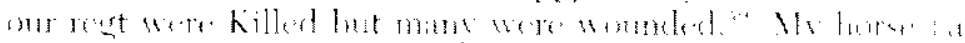

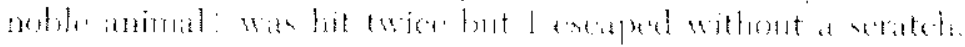

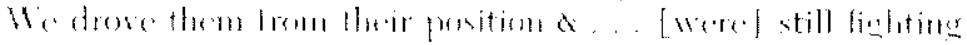

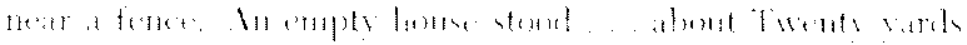

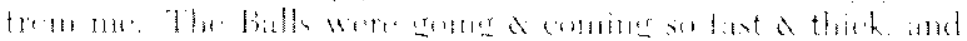

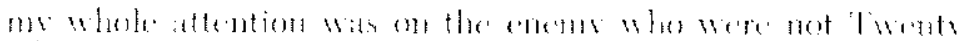

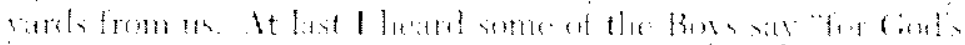

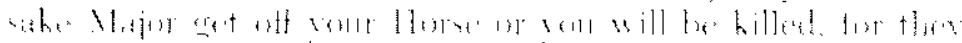

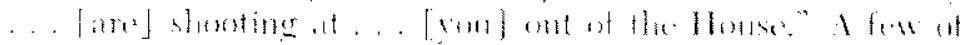

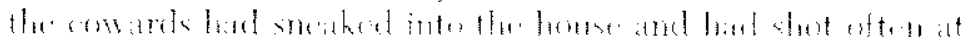

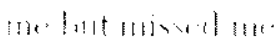

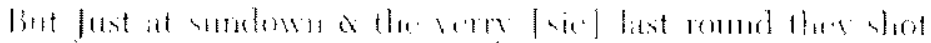

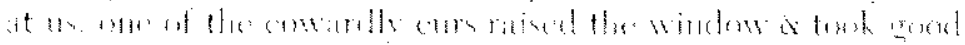

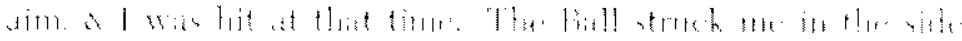

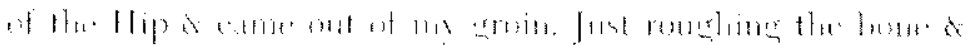

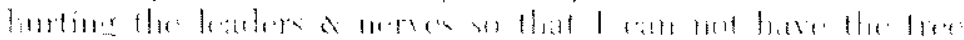

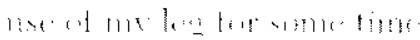

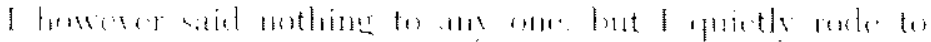

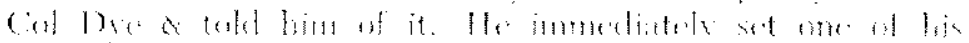

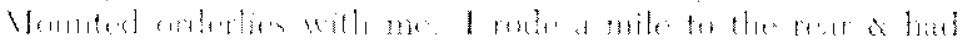

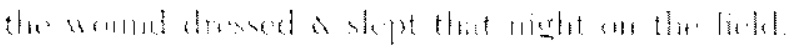

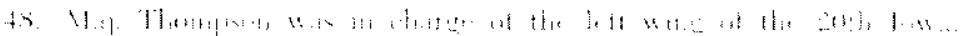

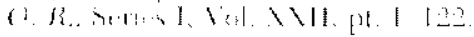

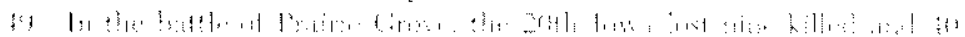

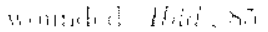

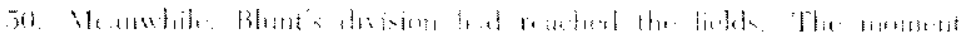

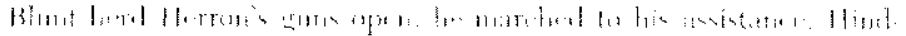

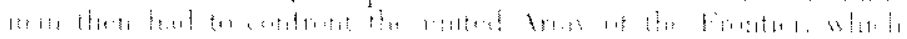

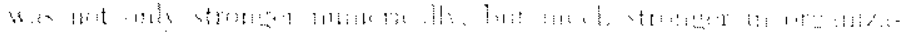

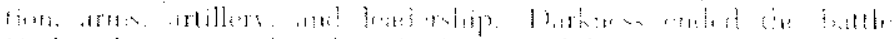

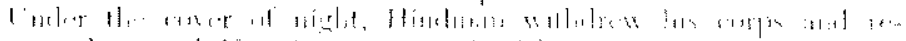

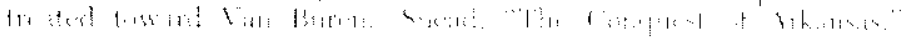

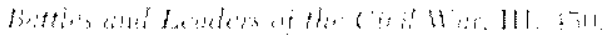




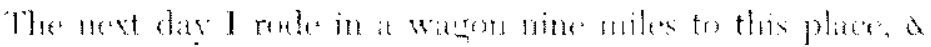
ligut [Frederick F.] Starek whe was wombled at the same

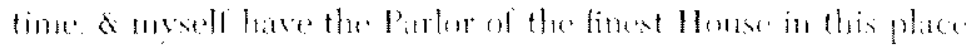

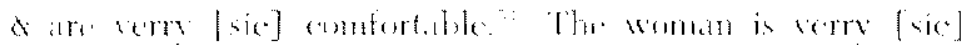
kimls.

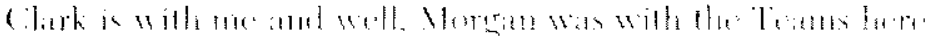

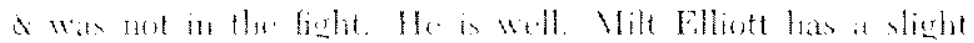
menum in the loced isher.

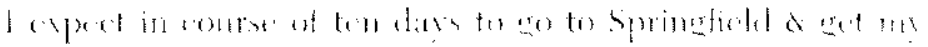

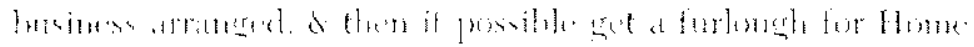

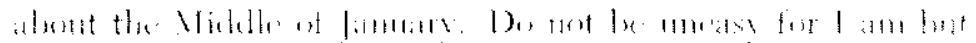

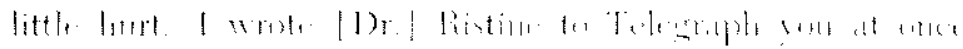

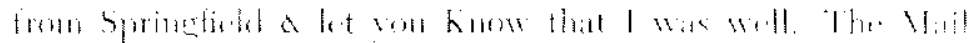

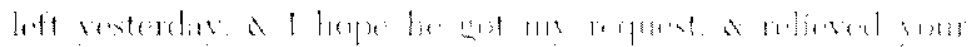

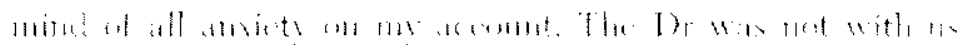

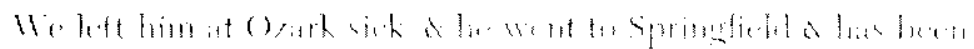

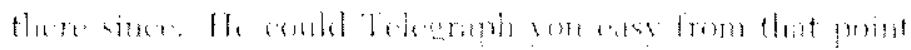

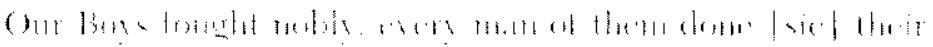

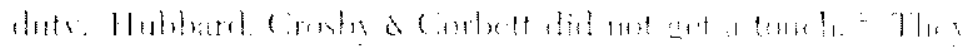

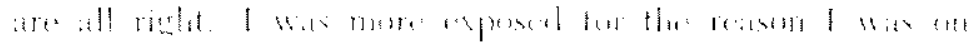

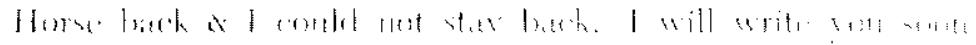

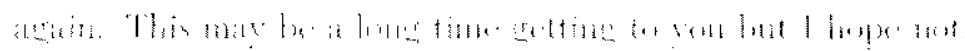

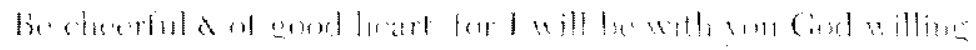

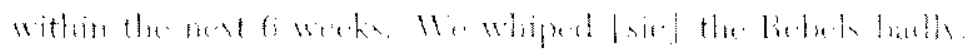

Find?

Hit ( Thrompun

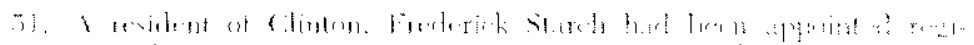

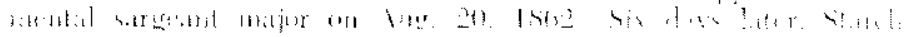

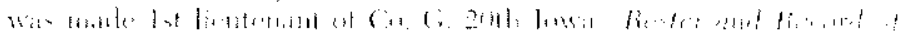

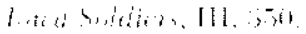

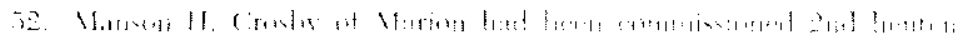

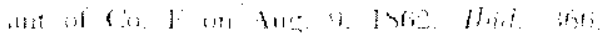


Copyright of Annals of Iowa is the property of State of Iowa, by \& through the State Historical Society of Iowa and its content may not be copied or emailed to multiple sites or posted to a listserv without the copyright holder's express written permission. However, users may print, download, or email articles for individual use. 